Shadow states and the black economy 
John F Mccarthy - 9789004260436

Downloaded from Brill,come4/26/2023 11:30:34AM via free access 


\author{
JOHN F McCARTHY
}

\title{
Sold down the river Renegotiating public power over nature in Central Kalimantan
}

In April 2004 a timber broker in Banjarmasin described joining a timber shipment down the Barito River earlier that month. An actor known as an ekspedisi took responsibility for a huge raft of timber complete with custom built shelters for those taking the three week trip along this major river. The shipment itself was also often known as ekspedisi. Stretching over two kilometers long, and comprising of $123,000 \mathrm{~m}^{3}$ of timber, the ekspedisi required several tug boats to pull the logs, each costing 60 million rupiah to hire. Three hundred gangsters (preman) armed with machine guns protected it. To entertain brokers accompanying the timber shipment, preman, rogue officials (oknum) and others occupying key posts along the watercourse, the actor behind the shipment provided prostitutes, marijuana, ecstasy and other drugs. These ekspedisi shipments are extremely expensive to operate, and given their size and the length of their journey, difficult to hide from local officialdom. Yet, the ekspedisi only had documents for $30,000 \mathrm{~m}^{3}$ of timber. ${ }^{1}$ Like virtually everyone active in the resource sector, the ekspedisi necessarily negotiated its way in the twilight zone between legality and illegality.

The ekspedisi system came to the attention of the national press in May 2002. At this time, in the district of Barito Selatan, a team of provincial police confiscated a consignment of 200,000 $\mathrm{m}^{3}$ timber - over 54,000 logs worth approximately 100 billion rupiah (approximately US\$ 10 million) - being shipped down the Barito River without a full set of official documents (Kompas 20-6-2002). Press reports focused on the illegality of the ekspedisi, carrying allegations of collusion between the district governments found along the river and the ekspedisi (Banjarmasin Post 30-5-2002). For the newspapers at

1 Interview with a timber broker, Banjarmasin, 26-4-2004. The most common meaning of ekspedisi is as in English, an excursion undertaken for a specific purpose, but it is also a technical term for (a business that does) cargo forwarding, such as sending parcels by ship. 
least, these stories were confirmed when the head of the district issued postfacto transport permits (SKSHH, Surat Keterangan Sahnya Hasil Hutan or susulan) and a letter (surat sakti) to the head of the provincial police requesting the release of the timber. However, rumours in the district contended that the police only confiscated the timber because the head of the provincial police deemed that the payments from the ekspedisi were insufficient. Finally, amid further insinuations of behind the scenes intrigue, the governor supported the district lobbying, even though releasing the timber in this fashion was technically in contravention of forestry regulations. To intimidate the police, or possibly provide a legitimate reason to release the logs, the timber interests behind the ekspedisi mobilized 1,500 'demonstrators' who descended on the shipment. In face of this show of force and a letter from the governor, the police finally allowed most of the logs to proceed (Kompas 13-6-2002). In a symbolic nod towards laws for processing 'illegal timber', the police auctioned a small amount of the logs.

While this story pointed to the struggle over access to the extensive benefits to be gained from this province's extensive forest resources, it only touched upon the extent and unremitting nature of this struggle. In addition to the district government agencies and the police, business interests, preman, indigenous entrepreneurs and remote villagers vied with or accommodated each other in attempting to maximize their benefits. While this struggle sharpened as Indonesia embarked upon a rapid decentralization process in 1999, it shifted with subsequent political, economic and legal changes, reaching a turning point when, after 2002, the central government recentralized areas of administration, especially with respect to forest management.

This chapter examines how decentralization and the subsequent recentralization affected the exercise of public powers over nature in Central Kalimantan. As actors attempted to shape these fluctuating conditions for their own ends, some actors have managed the transition well, others have seen the initial gains of 1999-2000 washed away. The central analytical problem requires analyzing the connection between changes in the modes of resource control under regional autonomy and the changing patterns of political representation, participation, and power. This involves connecting recent theoretical understanding of the mechanisms, the structures and the processes at work in the control of natural resources and the wider literature concerned with civil society, the state and power. My objective is to draw some conclusions concerning the functioning of civil society, the state and the exercise of power and the prospects for successful decentralization in this particular context.

This chapter advances two related arguments. First, the turn to and away from decentralization in the forestry sector over 1998-2004 involved a struggle over resources that reveals the particular course of politico-legal change 
over this period. During the high season of regional autonomy pre-existing localized modes of exchange and accommodation became more autonomous of the previously dominant centralized mode of resource control. As these decentralized modes of access flourished under regional autonomy, rents were more widely spread. While this allowed a wider range of strategically situated local actors to benefit, due to the structural disadvantages they faced, poor rural actors only gained short term and limited benefits. Over time the older system became more apparent: as corporate interests adjusted, they incorporated district elites and administrative structures as well as key rural actors into their processes of resource access. Just as colonial regimes inevitably incorporated local elites, predominant economic interests found ways to cooperate with and incorporate local strongmen, administrative and village elites. In this way the decentralized modes of resource extraction which have received so much bad press articulated with still dominant centralized modes.

Second, the constellation of actors benefiting from this system of resource access was highly changeable as the system was subject to shifts in power, political position, and legal authority. As district and upriver actors depend on personalistic, clientelist ties to officials occupying positions in various state agencies and to outside financiers and timber interests, they are particularly vulnerable to legal-administrative and political changes, particularly those that affect state based patrons in an administration under transition. The nature of these changes over 1998-2002 led to considerable changes in the constellation of actors benefiting from the system. While district actors and administrators had exceptional opportunities to gain benefits during 1999-2002, since 2002 the pendulum has swung back the other way as central government has slowly reconstituted its authority. This began when the police gained authority to apply sanctions in the forestry area. Under a command structure, still under the control of the central government, they increasingly deployed this against nonconforming district administrations. At the same time the Ministry of Forestry successfully recentralized areas of forest administration with Government Regulation no. 34/2002. Central government authority was again confirmed with the passing of a new regional government act (Law no. 32/2004) that stressed the authority of provincial governors just at the time when the political system was consolidating under the new president Susilo Bambang Yudhoyono and his vice-president Yusuf Kalla. These changes meant that once again actors with strong links in Jakarta and reaching down to governors and provincial police chiefs are once again in the best position to benefit from resources. While they have lost many of their formal powers they enjoyed over 1999-2002, state based actors in the local domain still retain an informal capacity to manipulate other actors access to market. 
In discussing developments in Central Kalimantan, I will analyse how the mechanisms, structures and processes at work in the control and maintenance of access to benefits have changed (Ribot 1998). For convenience, I will do this by dividing up the discussion into three sections, covering, first, the period immediately before regional autonomy, second, the high season of autonomy (2000-2002), and third, tracing developments from 2002. But first, I will discuss some theoretical considerations.

To understand the impact of regional autonomy on patterns of resource use, the concept of 'access' is central. Access has been defined as the ability to derive benefits from natural resources (see Ribot 1998:308). As actors struggle to benefit from the productive use of natural resources, they make use of a range of social, economic, and legal mechanisms. Legal frameworks, institutional power, group membership, social or ethnic identity, social status, the dynamics within a resource-controlling group, access to the state, to capital, to material resources, to customary authority, to markets, to knowledge and the ability to use institutional mechanisms are all factors that affect the process of gaining access to resources (Berry 1989; Ribot 1998; Ribot and Peluso 2002).

The main point is not whether access is considered legal or extra-legal, or legitimate or illegitimate according to various normative views (Ribot 1998). Access primarily depends on an actor's ability to dominate or influence other actors. Patterns of resource access can ultimately be understood in terms of how power is allocated and exercised within a society (compare Berry 1989). Central to this analysis then will be an analysis of how regional autonomy in Central Kalimantan has affected relations of power, encompassing both the legal and de facto loci of control. This means it is important to trace first, the changing prescriptions of law regarding property, permits, licenses and titles and official structures of authority, and second, changes to the whole ensemble of mechanisms shaping access - 'the structural and relational forces' - that exist 'prior and parallel to' socially recognized sets of rules (Ribot 1998:310).

Consequently, we need to understand how the changes associated with decentralization or regional autonomy have affected the structure of political, economic and legal relations that govern conditions of access. For, as the dominant discourses and the structures of power change, institutionalized mechanisms governing resource access are adjusted. When the existing institutional arrangements and social relations are restructured, new modes of identity and action are created, and new categories of people may rise to pre-eminence (Berry 1989:43-4). Yet, such a structural analysis needs to be supplemented by an actor oriented approach, because, within the changing patterns of political representation, participation, and power under regional autonomy, actors take up new strategies. As they attempt to shape conditions for their own ends, this in turn affects patterns of access and use. 


\section{The late New Order}

The New Order system of governance has been analysed in terms of horizontal and vertically integrated networks of power and interest largely financed with extra-legal revenues, including those derived from the timber sector. ${ }^{2}$ Under this system powerful politico-bureaucrats pursued entrepreneurial activities and extracted rents where possible, either for self enrichment, to command the loyalty of others both within and outside the pecking order, and/or to sustain the political interests of the institutions in which they were embedded.

This was particularly apparent in the forestry sector where an apparently centralized state system controlled access to resources. Under the Basic Forestry Act (no. 5/1967) the State - namely the Ministry of Forestry and its line agencies - controlled access to benefits via a concession licensing system (McCarthy 2000). As is well known, actors with access to key decision-makers within the regime, such as top military officials or cronies of the president, obtained legalized timber concession permits (Hak Pengusahaan Hutan, HPH). Given the close relations between the politico-bureaucrats controlling access and the corporate actors mining the forests, during field operations the legal strictures pertaining to state control over forest access remained primary to obtaining access. In parallel with these legal rules there existed a well established but unwritten set of rules regarding how the benefits of resource access were divided in the process of obtaining various licenses and permits, in working forest areas, in transporting logs downriver, and exporting timber overseas.

During this time Central Kalimantan became, as a local academic described it, the 'kitchen' of the concession system. To open the area to exploitation, a state forest mapping exercise (Tata Guna Hutan Kesepakatan, TGHK) classified $75 \%$ of the province's surface area (20.2 million hectares) as national forest estate (kawasan hutan) and some 9 million hectares of this area as 'production forest'. Disregarding indigenous property rights in these areas, the ministry of forestry granted 108 timber concessions $(\mathrm{HPH})$ of 20 year duration to exploit these areas. Accordingly to one estimate, concessions operating in these areas at one point supplied an estimated $40 \%$ of national log supply each year (Kompas 18-6-2001).

At this time companies holding timber exploitation licenses paid the cost of processing the required licenses and permits and the formal taxes and duties that needed to be paid on legal timber. Even if they processed the requisite permits, they still faced the expense of making well-established

2 For discussion of this phenomenon, see C. Barr 1998, 2002; Robison and Rosser 1998; Robison 2002; MacIntyre 1994. 


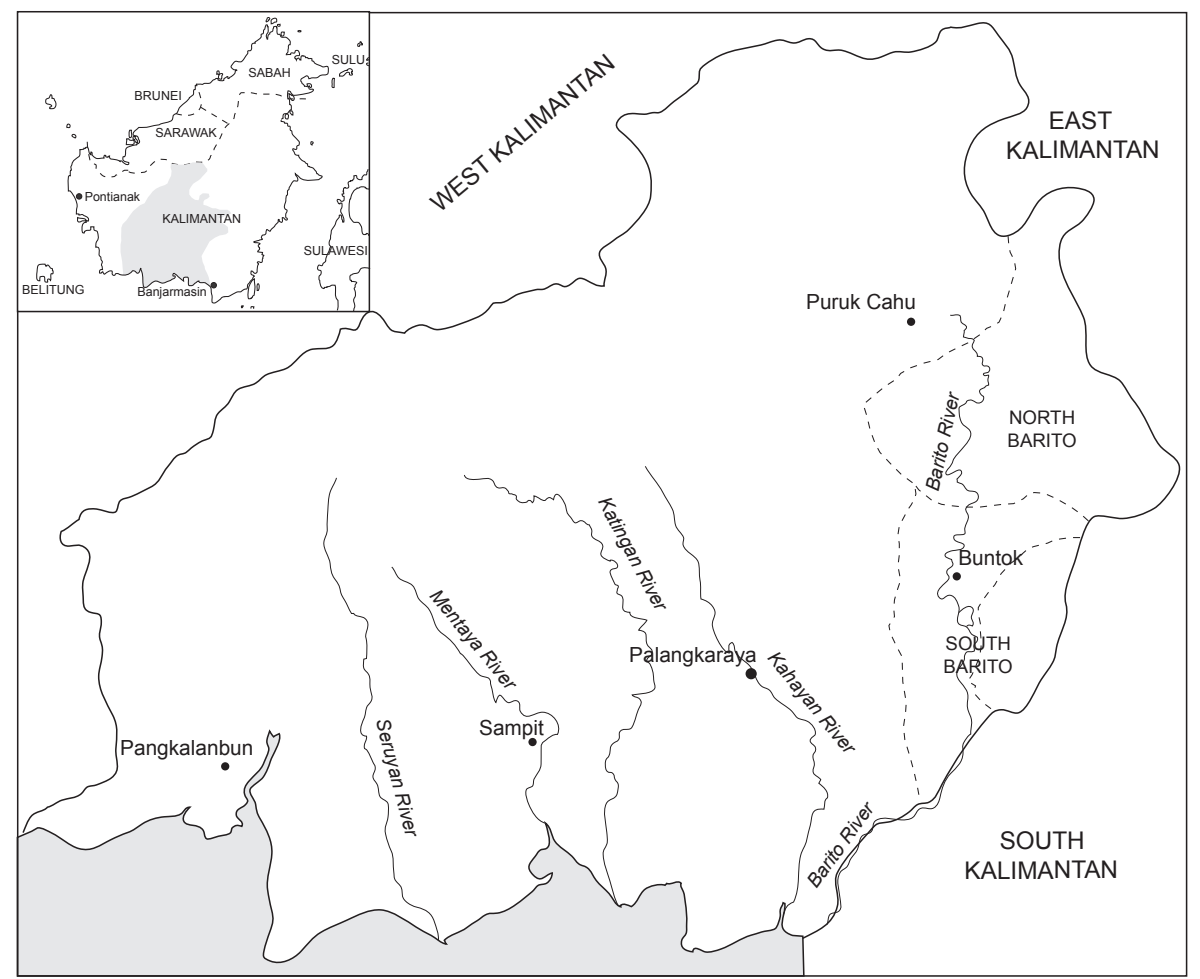

Map 6. Central Kalimantan 
payments to police, military, forestry and local government officials whose concurrence was needed for smooth operations in the field or along the river as they transported timber to market. To maximize profits, timber operators sought to minimize formal taxes and duties and the cost of obtaining permits. Mostly they extracted timber beyond their legal quotas and in areas adjacent to their legal areas. This meant that they needed to transport timber downriver well in excess of the amount for which they had documents.

Under the concession system, companies with official HPH concession licenses along the Barito River usually ran integrated operations that encompassed logging large areas, transporting timber downriver, and finally exporting sawn timber or plywood. However, the actor holding a concession license might also sub-contract various functions to other operators. In parallel with the vertically integrated concession system, other actors sold their services to concessionaires, such as shipping timber downriver. According to sources involved in these shipping operations, if the concessionaire had full documents for a shipment, they would use company barges (tongkang). However, if the shipment lacked full documentation they would engage the services to what had become known as ekspedisi, a sub-contractor shipping timber downriver. On average, ekspedisi would only obtain permits for approximately $30 \%$ of the timber they transported. Given the significant taxes thereby avoided, ample funds were left over to make the payments required to navigate the informal system. ${ }^{3}$

In parallel with the institutional order working down from Jakarta, as I have described elsewhere (McCarthy, forthcoming), during the New Order a system of resource extraction operated in outer island Indonesia that demonstrated the primary institutional arrangements characteristic of these areas. These consisted of self-regulating networks of exchange and accommodation that determined access to and use of key local resources which formed the most serious obstacle to the operation of formal state policy at least as it appears in policy documents and laws. The logic of this system is clear: over long periods of time state decision-makers in distant Jakarta have developed nation wide organizational rules pertaining to the local domain - specifically with regard to state forest. Yet, these rules failed to accommodate the interests of diverse actors and the variety of situations found in the local area (see Ostrom 1992). These interests included the extra-budgetary needs of local political actors and officials to maintain the local state apparatus, to sustain political loyalties, and to meet their personal economic ambitions. The state order also failed to meet the ambitions of local entrepreneurs disadvantaged by regulations that privileged those able to obtain forest exploitation per- 
mits in distant Jakarta, as well as the requirements for labour and economic opportunities for villagers disadvantaged by a state concessions system that allowed the logging customary lands in a fashion widely held to be unjust and inequitable.

Under the localized system of resource extraction that emerged, local entrepreneurs handled quasi-legal timber operations, sometimes in cooperation with outside concessionaires. They could do so as long as they conformed to a system of reciprocities that involved extra-legal gifts, payments and political support and other exchanges with key local politicians and state functionaries. These systems of extraction worked under the blind eye of local officials who were otherwise loyal to the regime. As they evolved, they grew into encompassing webs of exchange and accommodation that included forestry staff, army personnel and other key local functionaries while reaching out into the wider society to encompass village and adat heads. In many cases local bosses with access to capital and contacts and kinship relations within state agencies, with the agents of centralized concession operators and local police and military officials played key roles within these arrangements. While legal state sanctions would not be applied against those conforming to the reciprocities regulating this system, the legal domain of the state and those empowered by it remained central to the system. Officials within these networks derived their power from their capacity to issue permits, enforce state regulations and apply state sanctions. While this involves state power, these arrangements are not coincident with the state. Within complex evolving situations, to varying degrees the institutional arrangements governing access to resources both reflected and refracted customary local notions of rights, clientelist patterns of exchange and accommodation, and state laws within an institutional matrix working in an overlapping, and complicated fashion across these three institutional orders (McCarthy, forthcoming). Consequently, as Barbara Harriss-White (2003) has noted when discussing similar systems in India, the precise boundaries of the state remain blurred. Viewed from this angle, the state appears as a system or a set of bureaucracies 'that resists straightforward analytical closure' (Gupta 1995:392). Thus, the power of actors occupying positions in the state lies in their ability to manipulate other actors' access to market (see Reno 1995).

This became particularly evident in Central Kalimantan during the 1990s, when Suharto pushed a peat project, the notorious Peat Land Development Project (Project Pembangunan Lahan Gambut, PLG). As this mega-project aimed to convert one million hectares of peat swamp forest in southern Central Kalimantan to rice and other crops, it allowed for the wholesale clear felling of the peat swamp forests of southern Central Kalimantan. During this process, timber brokers connected to companies with valid permits to log particular areas would provide advances to loggers in the form of food 
or cash, or buy the timber directly from villagers working in surrounding areas. After purchasing logs, they would sell them on to sawmills that opened along the banks of the major rivers, or directly down to Banjarmasin, the major port for South-Central Kalimantan and the seat of major plywood and timber exporting factories, making considerable profits along the way. This system was operated by financiers from the timber companies who had placed orders with the local entrepreneurs and brokers, organizing for shipments of logs to be sent to Banjarmasin or further a field to Surabaya and Jakarta. These transactions occurred in collusion with district and provincial forestry staff, local military officers, the police and other local government staff. These officials received extra-legal payments on a regular basis. This meant that loggers received early warning of law enforcement, and cases of illegal logging were 'solved' in local coffee shops. ${ }^{4}$

With the police still under the armed forces, ABRI (Angkatan Bersenjata Republik Indonesia, Indonesian Armed Forces) was a leading agency in these processes. According to one source, the regional commander (Danrem) appointed individual district commanders (kodim), taking into account their promises regarding the amount of money they would 'store' upwards to the military command. This was just one of the unofficial ways the military obtained additional income. In Central Kalimantan well before regional autonomy, well-connected entrepreneurs and local timber interests at the district level in the interstices of the New Order state.

\section{Regional autonomy}

Even before the key autonomy law (Law no. 22/1999) had come into effect, district governments had gained greater legal authority in the forestry sector. They were, for example, entitled to grant small scale logging licenses. ${ }^{5}$ Under regional autonomy districts set up district forestry offices (dinas) that were accountable only to the district head and these now operated according to new district regulations (perda) rather than the directives of the Ministry

4 Tim Pemantuan Kawasan Konservasi Air Hitam, Kabupaten Barito Selatan, Kalimantan Tengah, lindungilah ekosistem air hitam dari ancaman Proyek Lahan Gambut (PLG) satu juta hektar di Kalimantan Tengah, laporan lapangan pemantauan kawasan konservasi air hitam di Kecamatan Dusun Hilir dan sekitarnya, 1997.

5 In 1999 a Ministry of Forestry initiative encouraged community groups to form cooperatives to obtain thirty-five year 'community forestry leases' (Hak Pengusahaan Hutan Kemasyarakatan, HPHKM) which could be issued by district governments. A government regulation (no. 6/1999) also established the concept of Forest Product Harvest Concessions (Hak Pemungutan Hasil Hutan, $\mathrm{HPHH}$ ), giving the bupati power to issue permits for $\mathrm{HPHH}$ in areas of 'production forest' of up to 100 ha. 
of Forestry in distant Jakarta. These formal changes, combined with the discretionary powers gained by district administrations following regional autonomy, meant that districts gained a large degree of de facto control over the way resource policy worked in their districts. From 1999 onwards district administrations in Central Kalimantan began to issue timber licenses to local people operating in their own name or in the name a community group incorporated into a cooperative or 'farming group' (kelompok tani). District entrepreneurs also began to formalize their operations by obtaining more extensive licenses for timber mills which had until then to various degrees worked outside the law. ${ }^{6}$

Under this system, the national forestry department lost its capacity to operate as a vertically integrated agency with full technical responsibility for forests. ${ }^{7}$ In this way, regional autonomy entailed a significant change in the locus where those wishing to gain access had to invest, pay a fee or exchange a service. To the mortification of the Ministry of Forestry, after 1999 district officials became important gatekeepers governing access to forest resources found in their district. ${ }^{8}$

Yet, many permits could still be obtained from provincial and central government agencies, ensuring that decentralization led to the diversification of control over access to forest areas and markets. Competition intensified between different agencies and different levels of government to control access, as well as between actors who had invested in relationships at a particular level. ${ }^{9}$ Consequently, the state was less able to maintain the pretence of operating as a unitary actor, as it had now emerged in a more plural guise (McCarthy 2004).

In Central Kalimantan the New Order had acted like a predatory state, extracting large rents from the province's forests, despoiling the patrimony of the indigenous people while providing very little in way of collective goods, especially in remote rural hamlets. ${ }^{10}$ After the demise of Jakarta's author-

6 For descriptions, see McCarthy 2001a, 2001b.

7 Under Law no. 22/1999 the provincial forestry office (kanwil) were abolished and, after the formal commencement of regional autonomy in 2001, the dinas at the district level became primarily responsible to the district head. For, as Article 4 of the new law stated, autonomous regions 'shall respectively be independent and shall not have a hierarchical relationship to each other' (Law no. 22/1999, Article 4). As the dinas at the district level no longer reported to dinas at the provincial level, the Ministry now had to rely on the dinas at the provincial level to pursue their objectives.

8 See McCarthy 2001a, 2001b.

$9 \quad$ See McCarthy 2004.

10 This is exemplified by the poor infrastructure in the new district of Gunung Mas. While the extensive timber resources found here were extracted for decades, the state had yet to develop the most basic communications, transport, health and other facilities. In 2001, virtually all villages lacked electricity or telephone, and there were only 23 kilometres of sealed road in the 
ity in law and public discourse, rural people and district elites alike openly challenged the mining of the forests by outside actors. Now local group membership, social and ethnic identity became more important in determining who could legitimately gain access to resources in the local domain. For a long time villagers had resented the way outside interests - especially timber and mining companies close to the regime - had extracted resources without respecting their adat property. In villages across the province anger at the way outside interests had over-ridden adat property rights, at the role of in-migrants in extractive industries, and at the minimal benefits enjoyed by local people boiled to the surface (ICG 2001b; McCarthy 2001a, 2001b). In numerous disputes in remote areas those claiming adat rights exerted physical control over particular areas. These putra daerah ('children of the region') sentiments worked against outsiders exploiting resources subject to adat claims. Villagers asserted adat claims over local resources via demonstrations, blockades, and the threat of physical violence and asserted physical control over access to resources in areas around their villages, swiddens and forest gardens.

At the same time local elites railed against the way Jakarta based actors had over-stepped the local administration in gaining permits, and the fact that the lucrative process of resource extraction occurred without providing sufficient funding for the development of local infrastructure, while failing to allow local entrepreneurs to gain sufficient benefits from resource extraction. Antipathy against outsiders holding key positions within the local bureaucracy translated into moves to indigenize key positions in the bureaucracy. Local politicians used 'putra daerah resentments' to legitimize decisions that were seen to favour local interests. District elites, who felt they had not enjoyed a fair share of resource extraction during the New Order, now saw this as their turn to benefit. ${ }^{11}$

Those putra daerah close to officials or with the means of winning their favour gained prominence, using kinship, village or other contacts in the administration, exchanging favours and offering money to obtain small scale exploitation permits, permits to transport timber and sawmill licenses. District regulations (perda) and policies explicitly or implicitly favoured people with putra daerah status in granting formal exploitation permits. ${ }^{12}$ If these brokers and small scale entrepreneurs could work with groups of villagers, helping them to incorporate as cooperatives or merely enlisting their names

whole area of 10,804 square kilometres (McCarthy 2001). In contrast, one of the first acts of the new district of Gunung Mas was to build an effective road link down to the provincial capital of Palangkaraya.

11 This phenomenon was also found in other areas of Kalimantan. See for good example 'Rencana Menhutbun tidak disetujui wakil rakyat Kutai', Suara Kaltim 20-11-2000.

12 McCarthy 2001. See Peluso and Harwell 2001. 
on permit applications, they could process small scale timber concessions in the name of village collectivities.

With the explosion of resentment and demands by villagers upriver against conglomerates, a large number of disputes emerged between concessionaires and villagers. As concessionaires and outside financiers faced increased threats from local actors, with regional autonomy, timber conglomerates found they needed to renegotiate renewed access to resources. At least formally, they could still obtain permits in the old way, but it was no longer sufficient to just obtain exploitation licenses via the central government. Having gained more extensive powers under regional autonomy, assertive district heads began to issue short term exploitation permits to local interests inside concession areas, typically favouring putra daerah with kinship affiliations, or with political or economic ties, from the same area. In these and other ways, district heads could put pressure on conglomerates to negotiate access via district administrations. In Central Kalimantan, working with local businessmen, many concessionaires began to invest in other extraction strategies. Extending the system that had operated during the PLG period, conglomerates worked with local businessmen and brokers, with informal support from district heads and the governor. ${ }^{13}$ For example, Djajanti, one of largest timber conglomerates in Central Kalimantan, allowed local companies to harvest its concession areas, according to one of its commissioners, 'on the condition that they only sell to us'.

We worked out what our costs would have been if we had been working the areas ourselves. And that's what we've paid the companies now working our concessions', said Sudrajat. Sudrajat decided to take this course of action because it seemed more advantageous than having to strong-arm it with the district head. With their current powers, it is very difficult to get the district heads to back down. (Tempo 46, 24-7-2001.)

The conglomerates also needed to negotiate taxation and levies - formal or otherwise - imposed by the local government (Kompas 16-8-2001). The system had the virtue of raising significant district taxes (Pendapatan Asli Daerah, PAD) that benefited local government. Given corruption and collusion in the way the system operated, unofficially it also enriched those occupying key positions in the district administration.

Apart from incorporating district elites and administrative structures into their processes of resource access, entrepreneurs and outside companies also sought to integrate key rural actors. They preferred for instance to operate through a villager, a local cooperative registered with the district government,

13 Timber interests also contributed large amounts of funds for the governor of Kalteng at the time of the last elections (McCarthy 2001a, 2001b). 
or a community group who could obtain operating permits from the district government. In Central Kalimantan ethnic identity had become important: belonging to a particular village, ethnic or adat group gave an actor a sense of entitlement. By operating behind a person or group with putra daerah status, outside actors could more readily legitimize their operations. This also had an added advantage: with many villagers recruited into timber operations in one way or another, many benefited under this system, and this tended to dissipate many emergent 'vertical' conflicts. In a number of cases individual villagers worked as the front men of concessionaires, operating cooperatives in villages areas without involving fellow villagers or making sufficient compensation for exploiting their adat property. Conflicts between companies and villagers were often transmuted into conflicts between villagers engaged in cutting timber in their adat territories and those who felt left out. ${ }^{14}$ If extralegal activities were involved, the actors behind the permit protected their good name and avoided the risk of legal sanctions. If the actor behind the permit was an official, a person with several permits, an outside concessionaire, or someone who might wish to disguise the extent of their operations, this strategy helped to avoid scrutiny.

The system offered additional economic advantages. Government agencies found it difficult to effectively tax informal logging operations that did not have an office and were not formally registered as a company. Village logging teams, or those acting in the name of communities, did not pay central government taxes such as the PSDH. ${ }^{15}$ Yet, as their timber lacked official documentation necessary to take it to market, they would have to sell it to the first available buyer, usually 'bosses' such as owners of small sawmills or timber collectors. While these operators might be able to obtain documents that would enable them to transport timber within the district, they lacked the documentation necessary to market the timber outside the area. As timber without a full legal status had a lower price, conglomerates that could use production permits obtained from the central government to render the timber legal, could buy the timber cheaply from poor villagers, making considerable profits in the process. Further, given the long-standing over the harvesting of timber inside concession areas, concessionaires faced difficulties meeting their production targets (Kompol Eddy Hermanto 2004). By subcontracting village teams to log surrounding areas, concessionaires could avoid the appearance of illegality, access other sources of timber subject to adat rights, and co-opt villagers all at the same time. Consequently, villagers remained in a weak position after regional autonomy. Even if they could

\footnotetext{
14 Interview Dinas Kooperasi, Kapuas, 27-4-2004.

15 Provisi Sumber Daya Hutan, Forest Resource Royalty. Interview, Dispenda, Kuala Kapuas, 27-4-2004.
} 
muster the money to obtain forest exploitation permits from the district government, they needed to obtain exploitation or transportation permits, and these expenses were cumulatively beyond the means of village actors and small time brokers. Local brokers and villagers lacked the capital required to use heavy machinery, run a saw mill, or obtain the permits required to transport the timber to the market. ${ }^{16}$ Villagers might log village areas under exploitation permits granted by district administrations in the name of individual villagers or cooperatives set up in the name of community groups. Yet, this logging took place under the coordination of brokers financed from outside, or on behalf of concessionaires. Even after decentralization, those with control over capital and permits that allowed them to take timber through key nodes in the commodity chain where value was added, accrued the largest share of the profits (Zerner 2000).

We can see these changes affecting the operation of the ekspedisi discussed earlier. By 2000 the Barito River had become an insecure place. With up to 30 gangs of river pirates operating along the river, timber shipments faced the hazard of hijacking. At the same time government agencies were competing more extensively to extract benefits from the system. By 2004 there were 480 posts from Puruk Cauh down to Banjarmasin. A variety of state agencies including Polsek, Koramil, Forestry, local government revenue collection agencies (dispenda), village posts, and the River Police, the police unit for ports and the navy ran these posts to levy 'taxes' on passing timber. ${ }^{17}$

Faced with an uncertain business environment, these interests found it easier to mobilize local strongmen to organize operations upriver. Timber companies now more extensively used ekspedisi who could guarantee the arrival of timber downstream, which involved sharing profits to minimize risks.

The actors running these operations required considerable skills and audacity, with the amount of profit depending on how they handled these risks. This encompassed arranging all the payments and negotiations with the various administrative areas found along the river. The amount of money involved was not trivial: an ekspedisi might provide hundreds of millions of rupiah to the head of the security forces in a riverside district each time the ekspedisi passed (Kompol Eddy Hermanto 2004). The reasons for this were clear: law enforcement authorities who felt affronted by the level of payment had the capacity to seize a shipment or arrest the ekspedisi leader. District government leaders also derived large profits from ekspedisi. They could hold

16 Even under regional autonomy, those wishing to obtain a permit required considerable capital. In 2002 a recommendation for a HPHH permit could (informally) cost 10 million rupiah. In addition, other investments were required, for example to pay for aerial photographs and field surveys.

17 Interview with a timber broker, Banjarmasin, 26-4-2004. 
up a shipment, for instance if payments were not made. Shipments could therefore only proceed with the tacit agreement of district leaders.

Moreover, if the timber was confiscated, district heads could arrange for it to be processed according to the legal fiction that it had no owner and 'auction' it back to the ekspedisi (Kompol Eddy Hermanto 2004). Alternatively, as a shipment could be lost to hijackers or fall prey to an extortion racket run by a rival underworld gang, payments were required to rival preman working along the river. On occasion disputes led to casualties, if for instance the armed preman protecting a shipment became involved in a shoot out with river pirates, or the police and river preman engaged in a gun battle.

Given their capacity to bridge this crucial space in the commodity chain ekspedisi accumulated large amounts of capital. By 2002, in addition to working for concessionaires and Banjarmasin based timber mills, ekspedisi carried timber for freelance brokers who went upriver to place orders. Further, ekspedisi worked as entrepreneurs in their own right, overseeing timber operations upriver and taking timber from scores of local timber brokers. At the peak of the ekspedisi system, shipments could be over 3 kilometres in length (Banjarmasin Post 8-7-2002).

The risks involved in the system meant that only the strongest ekspedisi could survive. In 1995, according to one source, there were approximately six actors working as ekspedisi. By 2002, only four key figures straddled the link between local timber operators and buyers upriver and the market downriver in Banjarmasin, thereby becoming the key players in the forest sector for this area. As this process of 'natural selection' proceeded, in 2004 only two continued to work the river.

\section{Power, civil society and accountability under regional autonomy}

There are further issues to consider with respect to this system, the first of which concerns the nature of power in this out-of-the-way and long neglected province. Under regional autonomy the local administration had gained authority over licenses and permits, while the police retained power to enforce the law. At the same time, entrepreneurs, brokers and agents of Jakarta based conglomerates maintained a hold over productive processes through their control over capital and access to outside markets. While the wheels of this system were oiled by a range of accommodations and exchanges between actors, these arrangements extended way beyond simple transactions between the actors involved. If the system was to continue to operate with such a high degree of corruption and illegality, it needed to protect itself from unwanted scrutiny. Exposure outside the province could lead to law enforcement activities from external actors, or the demand for 
payments in exchange for turning a blind eye. With a national campaign against illegal logging, those with most to lose from the exposure of their operations were prepared to intimidate or take violent action against actors who might expose it. Consequently, in Central Kalimantan power is often naked in its expression.

In 2002, when I visited an upriver area with a large number of timber operations working outside the law, thugs (preman) followed my movements. Here an NGO activist described how some of these preman had tried to kill him by running his motorcycle off a remote road into some trees. While it is possible to discover who is benefiting and how, it is not always good for one's health or career to unravel the connections between modes of resource control and political power. ${ }^{18}$

Villagers remained relatively disadvantaged under decentralization. Yet, the system that flourished at this time led to a much wider distribution of benefits than the earlier centralized system. Ironically, this wider distribution of benefits also encompassed the key agents of what is often considered civil society. This became apparent when a reporter told me how all journalists in the provincial capital, Palangkaraya, received monthly payments from a major timber mill not to report on their activities. When villagers had burnt down the mill after a long festering dispute, the local press failed to carry the story. ${ }^{19}$ During a journey upriver, another journalist told me of a range of illegalities and corrupt activities he had uncovered in the area. After he left, others present described him as a 'journalist without a paper' (wartawan tanpa surat kabar or WTS, a word play on the Indonesian term for a prostitute). This freelance journalist travelled around with a press card uncovering illegalities and extracting blackmail money in exchange for suppressing publication. According to one report, a timber operator could face forty journalists visiting his office, asking for one hundred to two hundred thousand rupiah in exchange for not exposing illegalities. In a district along the Barito River, each time an ekspedisi passed, the ekspedisi would be given a list of the names of journalists who would need to be paid between five hundred thousand and five million rupiah not to report the ekspedisi (Kompol Eddy Hermanto 2004).

District officials and journalists also discussed a similar phenomena among NGOs, which they jokingly referred to as 'organizations that like to make requests' (Lembaga Suka Minta, a wordplay on the Indonesian term for NGOs, LSM or Lembaga Swadaya Masyarakat). With hundreds of NGOs

18 These realities also prevent the type of commodity chain analysis advocated by Ribot (1998), making it difficult to quantify the division of benefits from resource extraction pre- and post-decentralization.

19 Interview, Palangkaraya, 22-4-2004. 
emerging after the end of the New Order period, many NGOs in the province also collected information in upriver areas, extracting money from those involved in exchange for silence. ${ }^{20}$ According to a DPRD (Dewan Perwakilan Rakyat Daerah, District Assembly) member interviewed in Buntok, the capital of Barito Selatan district, every time an illegal timber shipment passed through Buntok, several NGOs received a payment.

NGOs and the press may be considered the key protagonists of modern civil society. Yet, rather than acting as the torch bearers of 'a moral community, a legitimate political order' (Khilnani 2001), many of the key actors in civil society acted like just another group of rent-seekers. With journalists and NGOs often in the pockets of commercial interests, it was hard to envisage the press taking on a critical role. There are also obstacles to the healthy development of what Jürgen Habermas (1992) has called a 'public sphere' - where public opinion formed through free discussion in the press informs and controls the activities of the state.

If democratic decentralization is about devolving powers to downwardly accountable actors (Agrawal and Ribot 1999), we can understand outcomes in terms of the way accountability relations encompass local government. Indeed, the main mechanisms of accountability set out in both Law no. 22/1999 and Law no. 25/1999 operated primarily through elected district assemblies (DPRD) that have the capacity to hold executive accountable. ${ }^{21}$ The underpinning assumption seems to have been that the legislative would use mechanisms at its disposal to police and punish government officials - including the head of the region - who misbehaved. But, with only a weak link between DPRD members and their constituencies through a poorly designed electoral system. According to DPRD members interviewed in the course of this research, collusion between elected representatives and the chief executive office, under the laws of 1999 still elected by the legislative, has distorted the operation of accountability mechanisms.

These problems become particularly evident at two key moments each year. In order to enhance the monitoring of executive behaviour and hence improve government performance, Indonesia's decentralization laws provide the DPRD with the power to reject the annual accountability report of the head of the region. In theory, if this report is not accepted, the district head

20 According to informants, only a few NGOs and journalists in Palangkaraya remained free of these corrupt influences.

21 Law no. 22/1999 speaks of the 'role of the DPRD in performing its function as the monitoring body in the implementation of regional autonomy', and the DPRD is meant to monitor and to improve government performance. For example, the head of the region is accountable to the DPRD (see Law no. 22/1999, Article 44 and 45), and the DPRD has the authority to reject the accountability report of the head of the region and even dismiss the regional head (Law no. 22/1999, Article 3). 
can be forced to resign..$^{22}$ According to a number of accounts from Central Kalimantan, the district heads pay money to members of DPRD to ensure the acceptance of their accountability report. Within the system of exchange that dominates district politics, the accountability report becomes a lever to extract business and other concessions from a district head, with DPRD members refusing to pass reports until agreement is reached regarding how district projects will be divided out. ${ }^{23}$ Expensive deal making also affects the arrangement of the annual budget. The head of the district assembly, the district head, the secretary of the district (sekda), heads of district agencies (kepala dinas), and heads of factions in the DPRD, are the major players in arranging the budget (RAPBD), obtaining projects worth millions of rupiah. In return for their acquiescence, DPRD members obtain projects and sums of money allocated 'for lobbying'. ${ }^{24}$

According to a disillusioned DPRD member interviewed in 2004, a career in the DPRD has become an object of accumulation both for personal and political ends. Candidates for the legislature need to invest in the party to become a candidate, and once a candidate is elected they need to earn money for the party to support re-election. ${ }^{25}$ To this end, they need to obtain lots of projects. Consequently, 'people are very disillusioned with politicians, they just see them as being after their own interests'. Given the dominant power of the executive in policy processes and the way collusive practices have corrupted the DPRD, community aspirations fail to be taken up by DPRD. It is hardly surprising that villagers have little expectations and, according to one DPRD member, they are not interested in meeting DPRD members visiting their constituencies. ${ }^{26}$

Members of the DPRD have also been involved in the timber trade, using their status within networks of exchange and accommodation encompassing the executive to provide operations with a degree of immunity from law enforcement. DPRD members have provided recommendations for timber to pass through their districts or supported the statements of timber interests in the name of the DPRD. More directly, it has been estimated that more than 60 DPRD members in Central Kalimantan have been directly involved in tim-

\footnotetext{
22 In late 2004 Law no. 32/2004 took away the power of the DPRD to hold the district head accountable in this way.

23 Interview, 11-8-2002. Interview DPRD member, Palangkaraya, 24-4-2004.

24 Interview DPRD functionary, Kapuas, 27-4-2004.

25 Under this electoral system, the position of a candidate on the ballot paper determines the likelihood of obtaining a seat in DPRD. Candidates who failed to gain a seat typically complain of collusive, corrupt practices determining the position the party allocated them on the ballot paper. 26 Interview DPRD functionary, Kapuas, 27-4-2004; Interview DPRD member, Palangkaraya, 24-4-2004; Interview NGO employee, Palangkaraya, 23-4-2004. Yet, given the lack of transparency, it is very difficult to know the political deals that take place, how projects are divided up, and how much an accountability report costs to get through the legislative.
} 
ber enterprises. ${ }^{27}$ This points to the reality that formal mechanisms of public participation and representation bear little resemblance to the actual mechanisms determining who gains access to resources and how they do so.

\section{Post autonomy: changes after 2002}

From 2000 two significant changes occurred that were to have far reaching consequences after 2002. First, in July 2000 Abdurrahman Wahid separated the police from the armed forces, a decision that took effect as of 1 January 2001 (ICG 2001b; Kompol Eddy Hermanto 2004). Prior to the restructuring of the military, the military and police were integrated into a unitary command structure. As the military was the lead agency, 'the police could be leant on by ABRI, and so they weren't so brave'. ${ }^{28}$ After the reforms the police reported directly to the president under a national police chief. As the head of the provincial police (kapolda) now had a rank of brigadier general while the head of the local military command (danrem) remained a colonel, the local police commander was superior in rank. Yet, like the military, the police remained under-funded and, according to one report, obtained only $30 \%$ of their operating budget from the government. At the same time the central government made no steps to improve accountability within the force, and - despite regional autonomy - there was no formal means of holding police downwardly accountable to the local population. ${ }^{29}$ To be sure, the provincial police chief (kapolda) remained accountable upwards to the central government. As the kapolda could be moved if Jakarta was dissatisfied with his performance, he remained in a subordinate position to the governor, the representative of Jakarta in the regions. Yet, with the governor's support, Jakarta reappointed the same person to the position three times, suggesting that the governor and the kapolda had worked out mutually agreeable arrangements. Consequently, as long as the kapolda tied in decisions with the governor, the district police chief (kapolres) could operate on his behalf outside the matrix of district accountability relations. ${ }^{30}$

27 The decision was formalized with the promulgation of the new police law in January 2002; Undang-Undang Republik Indonesia Nomor 2 Tahun 2002 Tentang Kepolisian Negara Republik Indonesia.

28 Interview, Forestry Official Kuala Barito, 25-4-2004. Within the regional hierarchy, the head of the regional military command (dandem) was a colonel with a higher rank (class c) than the head of the provincial police (kapolda) who was colonel with a rank of class g.

29 USINDO Open Forum Challenges to Police Reform in Indonesia, with Adrianus Meliala, lecturer at the University of Indonesia, 26 September 2002, Washington DC. Http://www.usindo. org/Briefs/Police\%20Reform.htm.

30 Interview, Palangkaraya, 22-4-2004. 
In 2000, an institutionalized committee (the Muspida) that included the local head of the administration, the local military and police chiefs - with the forestry agency handling operational matters - used to coordinate district policy as well as the distribution of revenue across agencies. At this time, given the history of military pre-eminence, a number of timber businesses still operated in this region under military protection. ${ }^{31}$

After 2002, making use of their new powers, the police began to work more autonomously of district civil and military commands. As the technical agency concerned with forests, forestry agencies had long competed with the police to control law enforcement in the forestry sector. While forestry officials had investigatory powers, they needed to report infringements of forestry law to the police whose responsibility it was to process the case until it reached court. ${ }^{32}$ Armed with their extended authority, now the police increasingly came down to confiscate timber without involving district forestry agencies. Although this left district forestry agencies primarily in control of permits and licenses, there was little district administrations could do. As district forestry agencies - and the wider district administration - saw the police usurping their authority and the revenue that followed from its application, jealousy increased between the police and the other agencies, including the military and the district forestry agencies.

The second change occurred when the Megawati administration began to reassert the control of Jakarta over far-flung provinces. Responding to the competition over control of forest resources, the national government moved to reassert vertical control with a key regulation that effectively worked against district timber regimes. In July 2002 the central government issued a new Government Regulation (no. 34/2002) pertaining to the forestry sector. Before this time, the authority of the ministry of forestry had been disaggregated. With a political struggle occurring in the centre, the laws pertaining to natural resource use and regional autonomy remained uncoordinated, inconsistent and contradictory. ${ }^{33}$ During this time there were serious dis-

31 McCarthy 2001a, 2001b. Primarily the Muspida (musyawarah pimpinan daerah) at the district level, but also the Muspika (musyawarah pimpinan kabupaten) at the sub-district level.

32 According to the criminal law (Law no. 81/1981), the police had the primary investigatory powers (penyidik tunggal). However, forestry laws (such as Law no. 41/1999) gave forestry officials investigatory powers for forestry related matters. These areas of law set the scene for long standing institutional competition between police and forestry officials.

33 In January 1999 a government regulation (no. 6/1999) established the concept of Forest Product Harvest Concessions (Hak Pemungutan Hasil Hutan, HPHH), giving the district head power to issue permits for HPHH in areas of 'production forest' of up to 100 hectare. On 13 November 1999, the new Minister of Forestry attempted to reverse the implementation of this policy. In 2000, another ministerial decision (Kepmenhut no. 051/Kpts/2000) once again gave regional governments the power to allocate concessions licenses. Kepmenhut no. 541/KptsII/2002 then cancelled this earlier decision. Finally, in 2002 with the passing of a more binding 
putes within the districts and among central and provincial authorities over natural resource decision-making. Finally, the Forestry Ministry regained control over the permit system, timber transport licences, and the collection of taxes on forestry activities, effectively rescinding district authority to issue 100 ha exploitation permits and raise district taxes in the sector. ${ }^{34}$ While the central government did not immediately repeal district regulations that contradicted the new regulation, district heads who continued with earlier policies faced legal sanctions.

With a national campaign against illegal logging, the police began to make law enforcement efforts that also made for excellent public consumption. Raids by the police concentrated on small scale sawmills and timber shipments run by local entrepreneurs and brokers, along with larger timber operations and some ekspedisi operating without full legal documents. Over time the police and the provincial courts began to act more aggressively against 'illegal logging', leading to their effective control over the forestry sector. District officials involved in administering district regimes were faced with arrest by the police for breaking national law. In a well known case, in 2003 the head of the forestry agency, the district head, the head of the DPRD in the district of Barito Utara all faced legal charges for providing transportation documents to an ekspedisi containing uncertified timber. They allegedly issued the documents according to a district decision in contradiction of national forestry laws that provide that timber without documents should be confiscated and auctioned. Provincial rumour held it that the case involved political competition and unhappiness regarding the division of revenues with other actors. Meanwhile, two senior officials in a neighbouring district faced charges for the fictive auctioning of timber, and the deputy head of the forestry agency in a third district also faced charges (Banjarmasin Post 3-3-2003).

Yet despite this apparent crackdown, according to one forestry official on the Barito River, 'if timber passes through with "the flag of kapolda on it", noone is brave enough to touch it'. 'Police can arrest us', he said, 'but we can't do anything to them'. ${ }^{35}$ According to a number of sources, a broker close to the provincial police chief was now the key gatekeeper in the province. Only

\footnotetext{
Government Regulation (no. 34/2002) did the Ministry successfully begin to curtail the capacity of districts to allocate concession licenses, but not before some districts granted a cache of new 10,000 hectare IPHK licenses within their territories.

34 The most stringent restrictions introduced by Government Regulation no. 34/2002 were that districts could only give permits for up to $20 \mathrm{~m}^{3}$; at the same time the provincial forestry agency tightened procedures for transporting timber, in effect taking back over timber transport permits. Interviews in Kapuas during 2004 revealed that, taken together, these changes stopped districts independently issuing new permits and made timber operations uneconomical for local businesses.

35 Interview, Forestry Official Kuala Barito, 25-4-2004.
} 
timber syndicates linked and making payments to this broker and with the informal blessing of the provincial police chief could continue to operate. This had led to a further round of 'natural selection', with actors lacking an excellent working relationship with this gatekeeper, or either failing to make speedy or adequate payments, facing legal sanctions. ${ }^{36}$

These developments led to several changes in the field. Before, with competition between the police and the forestry agencies, law enforcement remained somewhat unpredictable. But now, the extraction of timber became easier and more 'manageable' for the few syndicates that now were able to operate. Second, the district bureaucracy could no longer guarantee access to resources as they used to. With small scale timber licenses (HPHH) expiring, many small scale district operators found that they could no longer negotiate new permits. Third, after Government Regulation no. 34/2002, in a similar fashion as before regional autonomy, permits needed to be processed at the provincial level and in Jakarta. ${ }^{37}$ This increased the dependence of local operators on actors who could process permits (HPH with valid licences) or guarantee taking timber out. Fourth, as districts could no longer apply district regulations, a number of administrative practices for raising PAD (Locally Raised Revenues) and laundering timber could no longer be used. ${ }^{38}$ Accordingly, district revenues from the forest sector fell into decline. And so the high tide of regional autonomy in the forestry sector ebbed.

36 Interview journalist, Palangkaraya, 22-4-2004.

37 Interview second assistant district head, Kantor Bupati, 25-4-2004.

38 For example, prior to Government Regulation no. 34/2002, districts had at least two ways of dealing with timber. Timber lacking the required permits could be 'caught' and handled according to a legal fiction that it had no owner. It would be 'auctioned' and sold on, and if the actor behind the shipment could negotiate this, the timber would be sold back to them. As the administration then issued legal documents, the timber (known as kayu temuan) then had a legal status. Alternatively, if an actor did not make these arrangements in advance, the timber could be confiscated (known as kayu tangkapan). Although the person making the shipment would be listed in the legal documents (berita acara), after sufficient lobbying with the district administration, the timber might be released to the owner, and legal documents would be issued after payment of district and (perhaps) central government taxes. Typically, the case would not proceed because of 'lack of evidence'. In the rare occasion that a case was taken to court, the offender would usually be instructed to pay PSDH without the application of criminal sanctions. While these methods generated revenue, they in effect laundered timber lacking the required documents. After Government Regulation no. 34/2002, the kayu temuan practice ended, while kayu tangkapan continued if the actor concerned could not make speedy and sufficient payments, or otherwise secure their operations via the dominant timber syndicates. 


\section{Conclusions}

Under the New Order cliques of politico-businessmen and their crony capitalist partners with access to the highest levels of the regime could deploy considerable power encompassing finance and business opportunities in faroff places. For instance, actors wired into networks of power in Jakarta could work concessions for themselves, fixing things upriver in due course. In doing so they could rely on the vertically integrated command-and-control structures that existed within state agencies such as the Ministry of Internal Affairs, the Ministry of Forestry and the Military which found their apex in the circle around Suharto. This vertical integration, together with the enduring nature of the regime and the rewards offered to those who remained loyal to the system, gave the New Order a sense of corporate coherence and autonomy seen as characteristic of developmental states (compare Evans 1995).

At the same time, before regional autonomy there were well established localized modes of resource control. As exemplified by the PLG project in Central Kalimantan, exchange relationships between district level officials and law enforcement agencies, entrepreneurs, brokers and strongmen formed a 'decentralized' system of resource access and control. In facilitating the extraction of forest resources from the area and its transport to markets controlled by financiers and corporate interests in far away Jakarta, this 'decentralized' mode of resource control articulated with the centralized mode. ${ }^{39}$

After the passing of the key decentralization law (Law no. 22/1999), political competition and conflicts over policy undermined horizontal ties within the state in Jakarta. At the same time, the decentralization laws hewed at the vertical connections within the state (McCarthy 2004). Between 1999 and 2002 district governments were freed from the command-and-control structures that had held them (to varying degrees) accountable upwards under the old regime. Institutional arrangements within the state became fragmented and contested, which reduced the capacity of the centre to set the rules and to enforce them.

Yet, despite the apparently drastic changes in the system after 1998, there was a great deal of continuity in the modes of resource access and control. Political decentralization had merely rearranged pre-existing 'decentralized' ways of organizing production and allowed them to flourish. With larger groups of actors involved in production and enjoying benefits, routes of access initially became more diverse.

To avoid the risk and hassle involved in running a business under these unpredictable conditions, outside financiers and business interests increas-

39 See Obidzinski (2003) for an extended analysis of how this mode of resource extraction operated over a long period of time in another area of Kalimantan. 
ingly subcontracted elements of their operations to local brokers, financiers and entrepreneurs. Given the importance of ethnic identity, these tended to be either putra daerah themselves, or actors who could involve putra daerah to arrange permits or operations in the villages and smooth relations with district elites. Over time local strongmen who could help guarantee the field operations of downstream conglomerates became more prominent, dominating the transport of timber out of the area. These figures gained a key role as intermediates between small scale brokers, entrepreneurs and loggers upstream and the financiers and industries downstream. Over time this led to a local centralization of control and benefit distribution around these strongmen. Ironically, decentralization had led to local centralization of this key node of resource control, a process which became more explicit after 2002.

A series of changes in the structure of state authority began to affect this system from 2001. With the strengthening of the status and institutional position of the police, the provincial police chief (kapolda) became more powerful. This allowed district police to operate under central control outside the matrix of district accountability relations. As the national government pushed for more rigorous law enforcement against 'illegal logging', the police began to apply the law against district and provincial actors involved in the sector. Yet, there were exceptions: a few syndicates with ties - via discreet gatekeepers - to the provincial police command continued to operate. At the same time, with the transition to the Megawati presidency, the central government wished to iron out the fragmented and contested state institutional arrangements. With a stated interest in reviving the unitary state, the administration set out to address some of the problems that had reduced the capacity of the central government to set the rules. In this context, the administration passed a key government regulation that reasserted the role of the ministry of forestry. This signified the end of effective district authority over forest permits. Consequently, the system for extracting resources became ever more centralized. These changes mark the re-establishment of a more vertically integrated system, where financiers and timber interests could expect greater predictability.

Over the 1998-2004 period, local actors faced a very fluid situation. Entrepreneurs, brokers, license holders and sawmill owners who had risen to prominence during the PLG period had to ride successive waves of legal, economic and personnel changes if they were to continue to prosper. After regional autonomy, change in politics and economics affected the personal situation of official sitting in the public sector agencies. The restructuring of the district and provincial agencies, changes in leadership, and the creation of new districts, were accompanied by a high degree of mobility in the public sector and changes in the authority and relative power of military, forestry, district and police agencies. This led to a process of 'natural selection', where 
only the strongest and most capable figures could survive. Those actors who could adjust, such as key local strongmen, needed to be able to use their multiple assets to insulate themselves from any particular change in the legal-political constellation.

Even if the logic of state action had been undermined during the messy process of implementing the decentralization reforms, the state remained important. Within public discourse, the application of state power still needed to be legitimated through the law. Yet at this time the legal system was contradictory. Consequently, state agencies at different levels of government relied on different areas of law within an inconsistent, rapidly changing legal framework. Here legality was first a matter of interpretation and perspective, which (as ever) was shaped for personal and institutional ends. The meaning of a law was coloured by shifting and contested interpretations of state regulations between competing agencies within a bureaucracy that was no longer so vertically integrated.

Localized matrices of power relations characteristic of these regions primarily regulated access and use of resources. The local state in its changing relations with provincial and centralized state authority remains primary to these networks. Above all, this is because those with the capacity to use state power locally necessarily will have to play the prominent roles within these networks of exchange and accommodation. Yet, given the informal nature of these institutional arrangements, they are best considered as neither coincident with nor independent of the local state.

Beyond the question of legal interpretation, a state agency - such as a district government, the ministry of forestry, or the police - needed to impose its interpretation in the field. A law could be used - through the threat or application of legal powers by a state law enforcement agency - to extract payments, to force an accommodation, to render an operation uneconomical, or to shut it down altogether. This depended on who had the authority or capacity to issue, obtain or manipulate documents, and who had the will or ability to enforce regulations at a particular time, and when, why and how they chose to do this. These applications of power in the field effectively regulated actors' capacity to extract resources from the system. By using this power, state actors in various ways controlled other actors' access to market, to various degrees accumulating revenue and enriching themselves in the process.

Initially district administrations set up district regulations that creatively used the centrally created legal system. At the high point of regional autonomy, well positioned district entrepreneurs and brokers improvised within the framework provided by these rules and the way they were applied, gaining windfall profits. The de facto control of villages over surrounding territories in the field meant that, for the first time in many years, conglomerates and financiers had to pay those claiming customary rights for access to resources. 
Moreover, the development of a permit system that allowed local people to legally extract resources gave upriver actors a chance to market timber resources within the law for the first time. To be sure these benefits were unfairly distributed in villages, and the rural poor remained disadvantaged. Nonetheless, the allocation of permits to local actors combined with the de facto control of villagers over surrounding areas strengthened the bargaining position of villagers, contributing to a wider sharing of benefits. This increased the relative value that local people gained from the mining of their forests. For villagers, entrepreneurs and district officials the legitimacy or illegitimacy of the system of resource extraction depended on its capacity to distribute benefits, rather than to any abstract notion of accountability or state legality. Here political, legal or physical activities of actors focused on ensuring their own participation in the clientelist system for distributing benefits rather than on the formal policy-setting functions of government.

Like the New Order before it, local government during the regional autonomy period set about raising revenue and extracting as much benefits from the forests as possible for political and other reasons while ignoring the ecological limits of Central Kalimantan's forests. Unfortunately, regional autonomy reforms also failed to establish the rights of local users in any enduring way (see Ribot and Peluso 2002:163). Consequently, with changes in state laws from 2002 onwards, recentralization abolished these district regimes and the capacity of a range of local people to benefit. The new decentralization laws (Law no. 32/2004 and Law no. 33/2004) further institutionalized this direction. The high season of regional autonomy had ended.

\section{Acknowledgements}

A heartfelt thanks to all those people who have helped me so much with this work in Central Kalimantan. For obvious reasons, sadly I am reluctant to thank you by name. Thanks to the participants of the KITLV project 'Renegotiating boundaries; Local politics in post-Suharto Indonesia' for their comments. Initial research was carried out in Central Kalimantan for the Australian Centre for International Agricultural Research (ACIAR) funded research project for the Centre for International Forestry Research (CIFOR) concerned with the evolution and impact of the decentralization of policymaking on forests and other sectors. I carried out further research in Central Kalimantan under a fellowship from the Van Vollenhoven Institute, Leiden University, during 2001-2003, and finally for the KITLV project 'Renegotiating boundaries; Local politics in post-Suharto Indonesia'. The article was written under an Australian Research Council grant at the Asia Research Centre, Murdoch University. 